DOI 10.22363/2312-8631-2018-15-4-398-409

UDK $378+517.9$

\title{
Humanitarian knowledge in the learning content to the inverse problems for differential equations
}

\author{
V.S. Kornilov \\ Moscow City Pedagogical University \\ 29 Sheremetyevskaya St., Moscow, 127521, Russian Federation
}

Problem and goal. Currently, humanitarization is a trend in the development of many scientific and educational fields, among which, undoubtedly, is applied mathematics.

The significant contribution of applied mathematics to the development of human civilization is obvious. At the same time, it is widely known that in some cases the practical implementation of applied research entails global environmental problems. There are irreversible negative processes in the environment. Such situations inevitably lead to a contradiction between the modern achievements of world science and its social and moral aspects. This problem is recognized not only by scientists. It is no coincidence that one of the directions of improvement of the Russian education system is the humanization of mathematical education, the concept of the content of which has been developed since the nineties of the last century.

One of the aspects of humanitarization of mathematical education is ecological education of students. A certain contribution to the formation of environmental education of students of physical and mathematical specialties of universities makes teaching inverse problems for differential equations, the content of which is formed on the basis of the theory of inverse problems for differential equations.

In this connection, in the process of teaching inverse problems for differential equations are realized such goals as: familiarity of students with the basics of humanitarian analysis of applied research, teaching students to formulate their own logical conclusions of applied and humanitarian character on the results of the study of the inverse problem for differential equations.

Methodology. The achievement of the above mentioned didactic goals of teaching inverse problems for differential equations is largely provided by how successfully will be implemented in practice such didactic learning tasks as:

1) realization of humanitarian potential of teaching inverse problems for differential equations;

2) formation of students' skills and abilities of independent analysis of applied and humanitarian nature of the results of the study of inverse problems for differential equations;

3) substantiation of the role of applied and computational mathematics in the development of human civilization.

In addition, in the process of teaching students inverse problems for differential equations it is advisable to implement a system of humanitarian-oriented training sessions.

This is due to the fact that in the process of such training students acquire fundamental knowledge not only in the field of mathematical methods of research of such applied problems. In the process of learning the inverse problems students are instilled features of humanization.

Results. In the process of teaching inverse problems for differential equations, students acquire the ability and skills to analyze the solutions of inverse problems, to formulate logical conclusions about the ecological state of the air space, the earth's environment or the aquatic environment, to apply numerical results of solutions to inverse problems in the humanitarian analysis of applied research. 
Conclusion. Fundamental knowledge in the field of inverse problems for differential equations, skills of using this knowledge in their professional activities, the possession of humanitarian culture, awareness of the humane relations of their applied activities with the environment and society contributes to the formation of students' spirituality, the development of worldview and awareness of involvement in the civilized development of society.

Key words: teaching inverse problems for differential equations, humanities, applied mathematics, student

Problem statement. Applied mathematical education is an important component of fundamental training of students of higher educational institutions. In the process of modern scientific research is characterized by the integration of science, the desire to get the most accurate representation of the overall picture of the world. At the same time, the achievements of modern nature sciences, which have general educational value, can not remain the property of only scientists. The essence and practical role of these achievements should be disclosed at a level accessible to students of higher educational institutions. These ideas are reflected in the concept of modern higher education. An important link in the implementation of the task of university training of future specialists in the field of applied mathematics, comprehensively developed, with a broad outlook, possessing deep theoretical knowledge and applied mathematical culture, is the mastery of their integrative system of knowledge. The principle of integrative knowledge involves the widespread use of interdisciplinary connections in the study of applied mathematics. This allows us to reveal the importance of applied mathematics in the development of world science.

Training in applied mathematics in organic connection with its history, scientific methods, people who made discoveries in it, the dependence of any science on applied mathematics allow to involve future specialists in the applied field to human culture as a whole. Applied mathematicians, as noted by Yu.N. Pavlovsky in the article [31], the humanitarian culture is necessary, humanists must have the basics of mathematical culture. This is possible only as a result of profound changes in the education system.

A significant contribution to the development of humanization of mathematical education introduced by A.D. Aleksandrov, N.In. Belotelova, Yu.I. Brodsky, N.I. Vilenkin, G.D. Glezer, G.V. Dorofeev, T.A. Ivanova, M.S. Kagan, S.A. Komissarova, G.V. Lavrent'eva, L.V. Mantatova, N.N. Oleneva, Yu.N. Pavlovsky, Yu.V. Senko, M.V. Simonova, N.L. Stefanova, A.A. Joiner, L.M. Fridman, I.M. Yaglom and other authors (see for example, $[2 ; 3 ; 7 ; 8 ; 10 ; 13-16 ; 24 ; 28 ; 29 ; 31 ; 35 ; 37])$. Humanitarization of mathematical education involves the study of mathematics in the context of all the achievements of world science and culture, which undoubtedly contributes to the development of students not only fundamental subject knowledge, but also cultural thinking.

Humanitarization of mathematical education involves the study of mathematics in the context of all the achievements of world culture, which undoubtedly contributes to the education of high spirituality, the formation of culture of future graduates, including graduates of physics and mathematics faculties. This should be formulated the value of mathematics in the intellectual, moral and spiritual formation of the individual, the role and place of the process of mastering mathematical culture in the education system, revealed the relationship of mathematics with the disciplines of the humanitarian cycle. 
According to A.D. Alexandrov, mathematics is a humanitarian Science in the sense that it deals with the study of human activity, without alienating It from the object of activity. A.V. Dorofeev thinks that a mathematical theory with a formalized presentation seem artificial, out of touch and incomprehensible. But if you approach them from the perspective of historical development, you will see their deep meaning of life and naturalness.

M.S. Kagan, analyzing the subject of the study of humanities and humanitarian knowledge, concludes that although mathematics has no special section associated with humanitarian knowledge, yet it has a certain specific humanitarian aspect - this is the aesthetics of mathematics. In the opinion of M.S. Kagan, this aspect was revealed by Pythagoreans at the beginning of the development of science on the number, and in the XX century, from judgments. Poincaré, mathematicians increasingly began to celebrate the beauty of human constructions (formulas, equations, theorems, geometric structures) and their aesthetic evaluation, thereby linking the humanitarian aspect of mathematics with its aesthetics. N.I. Vilenkin and I.M. Yaglom see the solution to the problem of humanization of teaching mathematics in the study of the history of mathematics and application of mathematics in humanities. G.D. Glazer draws attention to the aspect of scientific knowledge in mathematics and the history of mathematics associated with the humanization of mathematical education.

G.V. Dorofeev humanitarian focus of mathematics education discloses for the purpose of teaching: mastering the complex mathematical knowledge and skills; the formation and development of thinking skills, including heuristic and algorithmic; the formation and development of abstract thinking; the implementation opportunities of mathematics in the formation of scientific outlook; the formation of mathematical language; introduction to the role of mathematics in the development of civilization; introduction to the mathematical nature of scientific knowledge; formation and development of moral and ethical qualities of the person, adequate to process of full-fledged mathematical activity.

In their research, the authors combine the approach to the humanization of education as an integral part and means of the humanization process, aimed at familiarizing students with the humanitarian culture as a holistic social phenomenon, that such education is aimed at the development of deep and effective knowledge, mental operations, experience of creative activity. The authors draw attention to the fact that humanitarization is necessary in the logic of the educational process. In the real pedagogical process do not interact teacher and student, and real people, which the meanings of education brought together and, in in this context, as the subject of the training is not a goal, but a condition for the interaction of the participants of the pedagogical process.

With this approach, it becomes clear that no academic discipline has the privilege of being considered humanitarian in advance. Each may or may not be humanitarian, depending on how it is taught. Human knowledge is one and always humanitarian, because it is aimed at obtaining information about the world and at solving practical problems facing it. Therefore, it is impossible to divide knowledge, as noted by Mikhailov, into knowledge of nature and human knowledge. The humanitarization of education involves the rethinking of all components of the learning system: goals, content, methods, forms and means of learning (T.A. Ivanova). 
One of the aspects of humanitarization of mathematical education is ecological education of students. Currently, environmental specialties are in demand and function in many universities, including "Ecology and environmental management", "Geoecology", "Environmental management", etc. in the process of training in such specialties, students acquire fundamental knowledge of general ecology, social ecology, geoecology, applied ecology, the atmosphere, the biosphere, hydrosphere, etc. They form skills and abilities to apply modern environmental technologies in applied research.

The problem of formation of ecological culture among students finds its development in the research of not only ecologists, but also mathematicians, physicists, biologists, philosophers and other specialists. Among them N.V. Belotelov, Yu.I. Brodsky, A.V. Gagarin, M.M. Elanova, A.V. Ivashchenko, I.S. Ilyasov, G.I. Kushnikova, E.V. Muravyova, Yu.N. Pavlovsky, A.P. Petrov, E.V. Rahmatullina, S.A. Stepanov, S.M. Fairushina and other authors. Yu.N. Pavlovsky drew attention to the creation of a higher level of mutual understanding of mathematical and humanitarian studies that would allow the introduction of nature-saving technologies.

Method of research. Currently, humanitarization is a trend in the development of many scientific and educational fields, among which, undoubtedly, is applied mathematics. A certain contribution to the formation of ecological culture of University students makes teaching inverse problems for differential equations, the content of which is formed on the basis of the theory of inverse problems for differential equations.

Scientific approaches and mathematical methods of inverse problems for differential equations as a scientific direction of modern applied mathematics are widely used in applied research (see, for example, [4-6; 9; 12; 32-34; 36; 38]). The rapid development in the 40-50-ies of the last century of the theory and numerical methods for solving inverse problems for differential equations is largely due to the proposed in 1943. Tikhonov physically justified the concept of correctness of a mathematical problem and formulated In 1956 M.M. Lavrentiev's definition of conditional correctness of the mathematical problem, involving the use of additional information about the properties of the solution of this mathematical problem.

A significant contribution to the development of the theory of inverse problems for differential equations has made the study of Z.S. Agranovich, A.S. Alekseev, A.V. Baev, M.I. Belishev, A.S. Blagoveshchenskaya, G. Borg, A.L. Bukhgeim, P.N. Vabishevich, V.V. Vasin, A.O. Vatulyan, I.M. Gelfand, M.L. Gerver, V.B. Glasko, A.V. Goncharskii, A.M. Denisov, S.I. Kabanikhin, M.G. Krein, M.M. Lavrent'ev, V.A. Marchenko, A.I. Prilepko, V.G. Romanov, A.N. Tikhonov, V.A. Yurko and other authors.

The great need for the application of the theory of inverse problems for differential equations in applied research is explained by the possibility of effective study of hard-toreach or inaccessible to human objects and processes of different nature, determining their location, shape, structure of inclusions, etc., identifying their cause-and-effect relationships. All this, in many respects, became possible thanks to the use of modern information and telecommunication technologies. These circumstances explain the widespread introduction in the educational process of higher education students of physical and mathematical areas of training teaching inverse problems for differential equations (see, for example, $[1 ; 5 ; 6 ; 9 ; 11 ; 12 ; 14 ; 16-27 ; 32-34 ; 36 ; 38]$ ). 
In the process of teaching inverse problems for differential equations, students acquire fundamental knowledge not only in the field of mathematical methods for the study of such applied problems.

In the process of learning the inverse problems students are instilled features of humanization. Students acquire the ability and skills to analyze the obtained solutions to inverse problems for differential equations, to formulate logical conclusions about the ecological state of the air space, the earth's environment or the aquatic environment, to apply numerical results of solutions to inverse problems in the humanitarian analysis of applied research.

Results and discussion. Such logical reflections in the process of teaching inverse problems for differential equations contribute to the formation of students' skills in the humanitarian analysis of the nature of pollution of the earth's environment and air space, the system of knowledge about the role of inverse problems for differential equations in the humanitarian analysis of the properties of the water environment, the earth's environment and air space.

Fundamental knowledge in the field of inverse problems for differential equations, skills of using this knowledge in their professional activities, the possession of humanitarian culture, awareness of the humane relations of their applied activities with the environment and society contributes to the formation of students' spirituality, the development of worldview and awareness of involvement in the civilized development of society.

Conclusion. Orientation of higher mathematical education on humanitarian development of students is one of the actual principles of functioning of the system of modern Russian educational space.

Humanitarian-oriented training sessions on inverse problems for differential equations are aimed at creating situations that require students, based on the results of solving the inverse problem, to make logical conclusions of applied and humanitarian character, to overcome moral contradictions, to make a reasonable choice of the right position in society. From this point of view, inverse problems for differential equations can be considered as a moral application to various physical, environmental, social, economic, and other processes and phenomena.

(C) Kornilov V.S., 2018

This work is licensed under a Creative Commons Attribution 4.0 International License

\section{References}

[1] Bidaibekov E.S., Kornilov V.S., Kamalova G.B. Obuchenie budushhih uchitelej matematiki i informatiki obratnym zadacham dlja differencial'nyh uravnenij [The training of future teachers of mathematics and informatics inverse problems for differential equations]. Vestnik Moskovskogo gorodskogo pedagogicheskogo universiteta. Serija: Informatika i informatizacija obrazovanija [Bulletin of the Moscow City Pedagogical University. Informatics and Informatization of Education series]. 2014. No. 3(29). Pp. 57-69.

[2] Bidaibekov E.S., Kornilov V.S., Saparbekova G.A. Effektivnost' obucheniya studentov vuzov prikladnoj matematike $\mathrm{v}$ usloviyah gumanitarizacii matematicheskogo obrazovaniya [Learning Efficiency of University students applied mathematics in the conditions of humanitarization of mathematical education]. Vestnik Kazahskogo nacional'nogo pedagogicheskogo universiteta imeni 
Abaya. Seriya: Fiziko-matematicheskie nauki [Bulletin of Kazakh national pedagogical university named after Abay. Series of Physics and Mathematical Sciences]. 2015. No. 4(52). Pp. 13-18.

[3] Bolotelov N.V., Brodsky Yu.I., Olenev N.N., Pavlovsky Yu.N. Ekologo-social'no-ehkonomicheskie modeli: gumanitarnyj i informacionnyj aspekty [Ecological and socio-economic models: humanitarian and information aspects]. Informacionnoe obshchestvo [Information society]. 2001. No. 6. Pp. 43-51.

[4] Buhgejm A.L. Vvedenie v teoriju obratnyh zadach [Introduction to the theory of inverse problems]: monografiya. Novosibirsk: Nauka, Sibirskoe otdelenie, 1988. $181 \mathrm{p}$.

[5] Vatulyan A.O., Belyak O.A., Sukhov D.Yu., Yavruyan O.V. Obratnye i nekorrektnye zadachi [Inverse and incorrect tasks]: ucheb. posobie. Rostov-on-Don: Izd-vo Juzhnogo federal'nogo universiteta, 2011.232 p.

[6] Denisov A.M. Vvedenie v teoriyu obratnyh zadach [Introduction to the theory of inverse problems]: uchebnoe posobie. M.: Izd-vo Moskovskogo universiteta, 1994. 207 p.

[7] Elanova M.M., Mantatova L.V. Gumanizaciya obrazovaniya $v$ celyah ustojchivogo razvitiya [Humanization of education for sustainable development]: monografiya. Ulan-Udeh: Izd-vo VSGTU, 2006. $154 \mathrm{p}$.

[8] Ivanova T.A. Teoreticheskie osnovy gumanitarizacii obshchego matematicheskogo obrazovaniya [Theoretical foundations of humanitarization of general mathematical education]: dis. ... d-ra ped. nauk. Nizhnij Novgorod, 1998. 338 p.

[9] Kabanikhin S.I. Obratnye i nekorrektnye zadachi [Inverse and incorrect problems]: uchebnoe posobie. Novosibirsk: Siberian scientific publishing house, 2009. 458 p.

[10] Komissarova S.A. Zadachnaya tekhnologiya kak sredstvo gumanitarizacii estestvennonauchnogo obrazovaniya [Task technology as a means of humanization of natural science education]: dis. ... kand. ped. nauk. Volgograd, 2002. 215 p.

[11] Kornilov V.S. O mezhdisciplinarnom haraktere issledovanij prichinno-sledstvennyh obratnyh zadach [About cross-disciplinary character of researches of cause and effect inverse problems]. Vestnik Moskovskogo gorodskogo pedagogicheskogo universiteta. Serija: Informatika i informatizacija obrazovanija [Bulletin of the Moscow City Pedagogical University. Informatics and Informatization of Education series]. 2004. No. 1(2). Pp. 80-83.

[12] Kornilov V.S. Nekotorye obratnye zadachi identifikacii parametrov matematicheskih modelej [Some inverse problem of identifying parameters of mathematical models]: uchebnoe posobie. M.: MGPU, 2005. 359 p.

[13] Kornilov V.S. Gumanitarnaya komponenta prikladnogo matematicheskogo obrazovaniya [Humanitarian component of applied mathematical education]. Vestnik Moskovskogo gorodskogo pedagogicheskogo universiteta. Serija: Informatika i informatizacija obrazovanija [Bulletin of the Moscow City Pedagogical University. Informatics and Informatization of Education series]. 2006. No. 2(7). Pp. 94-99.

[14] Kornilov V.S. Obuchenie obratnym zadacham dlya differencial'nyh uravnenij kakfaktor gumanitarizacii matematicheskogo obrazovaniya [Training in inverse problems for differential equations as a factor of humanitarization of mathematical education]: monografiya. M.: MGPU, 2006. 320 p.

[15] Kornilov V.S. Gumanitarnye aspekty vuzovskoj sistemy prikladnoj matematicheskoj podgotovki [The humanitarian aspects of the university system of applied mathematical preparation]. Nauka i shkola [Science and school]. 2007. No. 5. Pp. 23-28.

[16] Kornilov V.S. Gumanitarnyj analiz matematicheskih modelej obratnyh zadach [Humanitarian analysis of mathematical models of inverse problems]. Izvestiya Kurskogo gosudarstvennogo tekhnicheskogo universiteta [News of Kursk State Technical University]. Kursk: KGTU, 2008. No. 3(24). Pp. 60-65.

[17] Kornilov V.S. Psihologicheskie aspekty obuchenija studentov vuzov fraktal'nym mnozhestvam [Psychological aspects of training of students of higher education institutions in fractal sets]. Vestnik Rossijskogo universiteta druzhby narodov. Serija: Informatizacija obrazovanija [Bulletin of Peoples' Friendship University of Russia. Informatization in Education series]. 2011. No. 4. Pp. 79-82. 
[18] Kornilov V.S. Laboratornye zanjatija kak forma organizacii obuchenija studentov fraktal'nym mnozhestvam [Laboratory sessions as a form of organization of teaching students fractal sets]. Vestnik Moskovskogo gorodskogo pedagogicheskogo universiteta. Serija: Informatika i informatizacija obrazovanija [Bulletin of the Moscow City Pedagogical University. Informatics and Informatization of Education series]. 2012. No. 1(23). Pp. 60-63.

[19] Kornilov V.S. Obratnye zadachi v soderzhanii obucheniya prikladnoj matematike [Inverse problems in the content of teaching applied mathematics]. Vestnik Rossijskogo universiteta druzhby narodov. Serija: Informatizacija obrazovanija [Bulletin of Peoples' Friendship University of Russia. Informatization in Education series]. 2014. No. 2. Pp. 109-118.

[20] Kornilov V.S. Obuchenie studentov obratnym zadacham matematicheskoj fiziki kak factor formirovanija fundamental'nyh znanij po integral'nym uravnenijam [Training of students in the inverse problems of mathematical physics as factor of formation of fundamental knowledge of the integrated equations]. Bjulleten' laboratorii matematicheskogo, estestvennonauchnogo obrazovanija i informatizacii. Recenziruemyj sbornik nauchny trudov [Bulletin of laboratory of mathematical, natural-science education and informatization. The reviewed collection of scientific work]. Samara: Samarskij filial MGPU, 2015. Vol. VI. Pp. 251-257.

[21] Kornilov V.S. Obuchenie studentov obratnym zadacham dlja differencial'nyh uravnenij kak factor formirovanija kompetentnosti v oblasti prikladnoj matematiki [Students learning the inverse problems for differential equations as a factor of formation of competence in the field of applied mathematics]. Vestnik Rossijskogo universiteta druzhby narodov. Serija: Informatizacija obrazovanija [Bulletin of Peoples' Friendship University of Russia. Informatization in Education series]. 2015. No. 1. Pp. 63-72.

[22] Kornilov V.S. Realizacija nauchno-obrazovatel'nogo potenciala obuchenija studentov vuzov obratnym zadacham dlja differencial'nyh uravnenij [Realization of scientific and educational potential of training of students of higher education institutions in the inverse problems for the differential equations]. Kazanskij pedagogicheskij zhurnal [Kazan pedagogicaljournal]. 2016. No. 6. Pp. 55-59.

[23] Kornilov V.S. Bazovye ponyatiya informatiki v soderzhanii obucheniya obratnym zadacham dlya differencial'nyh uravnenij [The basic concepts of informatics in the content of education inverse problems for differential equations]. Vestnik Rossijskogo universiteta druzhby narodov. Serija: Informatizacija obrazovanija [Bulletin of Peoples' Friendship University of Russia. Informatization in Education series]. 2016. No. 1. Pp. 70-84.

[24] Kornilov V.S. Teorija i metodika obuchenija obratnym zadacham dlja differencial'nyh uravnenij [Theory and technique of training to the inverse problems for differential equations]: monografija. M.: OntoPrint, 2017. 500 p.

[25] Kornilov V.S. Formirovanie fundamental'nyh znanij po matematicheskomu modelirovaniyu pri obuchenii obratnym zadacham dlya differencial'nyh uravnenij [Formation of the fundamental knowledge on mathematical modeling in teaching inverse problems for differential equations]. Vestnik Moskovskogo gorodskogo pedagogicheskogo universiteta. Serija: Informatika i informatizacija obrazovanija [Bulletin of the Moscow City Pedagogical University. Informatics and Informatization of Education series]. 2017. No. 1(39). Pp. 92-99.

[26] Kornilov V.S. Filosofskaya sostavlyayushchaya nauchno-obrazovatel'nogo potenciala obucheniya obratnym zadacham matematicheskoj fiziki [Philosophical component of scientific and educational potential of learning inverse problems of mathematical physics]. Vestnik Moskovskogo gorodskogo pedagogicheskogo universiteta. Serija: Informatika i informatizacija obrazovanija [Bulletin of the Moscow city pedagogical university. Informatics and Informatization of Education series]. 2018. No. 1(43). Pp. 59-65.

[27] Kornilov V.S. Formirovanie u studentov mezhdisciplinarnyh nauchnyh znanij pri obuchenii obratnym zadacham dlya differencial'nyh uravnenij [Formation of students' interdisciplinary scientific knowledge in teaching inverse problems for differential equations]. Vestnik Kazahskogo nacional'nogo pedagogicheskogo universiteta imeni Abaya. Seriya: Fiziko-matematicheskie nauki 
[Bulletin of Kazakh National Pedagogical University named after Abay. Series of Physics and Mathematical Sciences]. 2018. No. 4(64). Pp. 46-50.

[28] Kravets A.S. Gumanizaciya i gumanitarizaciya vysshego obrazovaniya [Humanization and humanitarization of higher education]. Vestnik Voronezhskogo gosudarstvennogo universiteta. Seriya: Problemy vysshego obrazovaniya [Bulletin of the Voronezh State University. Problems of higher education series]. 2000. No. 1. Pp. 30-37.

[29] Lavrentyev G.V. Gumanitarizaciya vysshego matematicheskogo obrazovaniya na osnove blochnomodul'nogo podhoda [Humanitarization of higher mathematical education on the basis of blockmodular approach]: dis. ... d-ra ped. nauk. Barnaul, 2001. 349 p.

[30] Levchenko I.V., Kornilov V.S., Belikov V.V. Rol' informatiki v podgotovke specialistov po prikladnoj matematike [The role of informatics in the training of specialists in applied mathematics]. Vestnik Moskovskogo gorodskogo pedagogicheskogo universiteta. Serija: Informatika i informatizacija obrazovanija [Bulletin of the Moscow City Pedagogical University. Informatics and Informatization of Education series]. 2009. No. 2(18). Pp. 108-112.

[31] Pavlovsky Yu.N. Imitacionnoe modelirovanie slozhnyh processov i sistem [Simulation modeling of complex processes and systems]. Sovremennye problemy prikladnoj matematiki [Modern problems of applied mathematics]: sb. nauch. statej. Vypusk 1. M.: MZ Press, 2005. Pp. 75-98.

[32] Romanov V.G. Obratnye zadachi dlya differencial'nyh uravnenij [Inverse problems for differential equations]: speckurs dlya studentov NGU. Novosibirsk: NGU, 1973. 252 p.

[33] Romanov V.G. Obratnye zadachi matematicheskoj fiziki [Inverse problems of mathematical physics]: monografija. M.: Nauka, 1984. 264 p.

[34] Samarskij A.A., Vabishevich P.N. Chislennye metody reshenija obratnyh zadach matematicheskoj fiziki [Numerical methods of the solution of the inverse problems of mathematical physics]: monografija. M.: Editorial URSS, 2004. 480 p.

[35] Simonov V.M. Didakticheskie osnovy estestvennonauchnogo obrazovaniya: teoriya i praktika realizacii gumanitarnoj paradigmy [Didactic bases of natural science education: theory and practice of realization of humanitarian paradigm]: dis. ... d-ra ped. nauk. Volgograd, 2000. $403 \mathrm{p}$.

[36] Timofeev Yu.M., Polyakov A.V. Matematicheskie aspekty resheniya obratnyh zadach atmosfernoj optiki [Mathematical aspects of solving inverse problems of atmospheric optics]: uchebnoe posobie. SPb.: Izd-vo Sankt-Peterburgskogo universiteta, 2001. 188 p.

[37] Fajrushina S.M. Formirovanie ehkologicheskoj kul'tury studentov pedagogicheskih vuzov v processe izucheniya estestvennonauchnyh discipline [Formation of ecological culture of students of pedagogical universities in the process of studying natural sciences]: dis. ... kand. ped. nauk. Kazan', 2007. $217 \mathrm{p}$.

[38] Yurko V.A. Vvedenie v teoriyu obratnyh spektral'nyh zadach [Introduction to the theory of inverse spectral problems]: textbook. M.: Fizmatlit, 2007. 384 p.

\section{Article history:}

Received: 25 June 2018

Accepted: 30 July 2018

\section{For citation:}

Kornilov V.S. (2018). Humanitarian knowledge in the learning content to the inverse problems for differential equations. RUDN Journal of Informatization in Education, 15(4), 398-409. DOI 10.22363/2312-8631-2018-15-4-398-409

\section{Bio Note:}

Kornilov Viktor Semenovich, doctor of pedagogical sciences, candidate of physical and mathematical sciences, full professor, deputy head of the department of informatization of education of the Moscow city pedagogical university. Contact information: e-mail: vs_kornilov@mail.ru 


\title{
Гуманитарные знания в содержании обучения обратным задачам для дифференциальных уравнений
}

\author{
В.С. Корнилов \\ Московский городской педагогический университет \\ Российская Федерация, 127521, Москва, ул. Шереметьевская, 29
}

Проблема и цель. В настоящее время гуманитаризация является тенденцией развития многих научных и образовательных областей, к числу которых, бесспорно, относится и прикладная математика.

Очевиден существенный вклад прикладной математики в развитие человеческой цивилизации. Вместе с тем широко известно, что в некоторых случаях практическая реализация прикладных исследований влечет за собой глобальные экологические проблемы. Происходят необратимые негативные процессы в окружающей среде. Подобные ситуации неизбежно приводят к противоречию современных достижений мировой науки и ее социально-нравственных аспектов. Это проблема осознается не только учеными. Неслучайно одним из направлений совершенствования российской системы образования является гуманитаризация математического образования, концепция содержания которой разрабатываться с девяностых годов прошлого столетия.

Одним из аспектов гуманитаризации математического образования является экологическое воспитание студентов. Определенный вклад в формирование экологического воспитания студентов физико-математических специальностей вузов вносит обучение обратным задачам для дифференциальных уравнений, содержание которого формируется на основе теории обратных задач для дифференциальных уравнений.

В связи с чем в процессе обучения обратным задачам для дифференциальных уравнений реализуются такие цели, как: знакомство студентов с основами гуманитарного анализа прикладных исследований, научение студентов самостоятельно формулировать логические выводы прикладного и гуманитарного характера по результатам исследования обратной задачи для дифференциальных уравнений.

Методология. Достижение отмеченных выше дидактических целей обучения обратным задачам для дифференциальных уравнений во многом обеспечивается тем, насколько успешно будут осуществлены на практике следующие дидактические задачи обучения:

1) реализация гуманитарного потенциала обучения обратным задачам для дифференциальных уравнений;

2) формирование у студентов умений и навыков самостоятельного анализа прикладного и гуманитарного характера результатов исследования обратных задач для дифференциальных уравнений;

3) обоснование роли прикладной и вычислительной математики в развитии человеческой цивилизации.

Кроме того, в процессе обучения студентов обратным задачам для дифференциальных уравнений целесообразно реализовывать систему гуманитарно-ориентированных учебных занятий.

Это обусловлено тем, что в процессе такого обучения студенты приобретают фундаментальные знания не только в области математических методов исследования подобных прикладных задач. В процессе обучения обратным задачам студентам прививаются черты гуманитаризации.

Результаты. В процессе обучения обратным задачам для дифференциальных уравнений студенты приобретают умения и навыки анализировать полученные решения обратных задач, 
формулировать логические выводы об экологическом состоянии воздушного пространства, земной или водной среды, применять численные результаты решений обратных задач в гуманитарном анализе прикладных исследований.

Заключение. Фундаментальные знания в области обратных задач для дифференциальных уравнений, умения и навыки использования этих знаний в своей профессиональной деятельности, обладание гуманитарной культурой, осознание гуманных отношений своей прикладной деятельности с окружающей средой и обществом способствует формированию у студентов духовности, развитию мировоззрения и осознания сопричастности к цивилизованному развитию общества.

Ключевые слова: обучение обратным задачам для дифференциальных уравнений, гуманитарные знания, прикладная математика, студент

\section{Список литературы}

[1] Бидайбеков E.Ы., Корнилов В.С., Камалова Г.Б. Обучение будущих учителей математики и информатики обратным задачам для дифференциальных уравнений // Вестник Московского городского педагогического университета. Серия: Информатика и информатизация образования. 2014. № 3 (29). С. 57-69.

[2] Бидайбеков Е.Ы., Корнилов В.С., Сапарбекова Г.А. Эффективность обучения студентов вузов прикладной математике в условиях гуманитаризации математического образования // Вестник Казахского национального педагогического университета имени Абая. Серия: Физико-математические науки. 2015. № 4 (52). С. 13-18.

[3] Болотелов Н.В., Бродский Ю.И., Оленев Н.Н., Павловский Ю.Н. Эколого-социально-экономические модели: гуманитарный и информационный аспекты // Информационное общество. 2001. № 6. С. 43-51.

[4] Бухгейм А.Л. Уравнения Вольтерра и обратные задачи: монография. Новосибирск: Наука, Сибирское отделение, 1983. 207 с.

[5] Ватульян А.О., Беляк О.А., Сухов Д.Ю., Явруян О.В. Обратные и некорректные задачи: учеб. пособие. Ростов на Дону: Изд-во Южного федерального университета, 2011. 232 с.

[6] Денисов А.М. Введение в теорию обратных задач: учебное пособие. М.: Изд-во Московского университета, 1994. 207 с.

[7] Еланова М.М., Мантатова Л.В. Гуманизация образования в целях устойчивого развития: монография. Улан-Удэ, 2006. $154 \mathrm{c.}$

[8] Иванова Т.A. Теоретические основы гуманитаризации общего математического образования: дис. ... д-ра пед. наук. Нижний Новгород, 1998. 338 с.

[9] Кабанихин С.И. Обратные и некорректные задачи: учебник для студентов вузов. Новосибирск: Сибирское научное издательство, 2009. 458 с.

[10] Комиссарова C.A. Задачная технология как средство гуманитаризации естественнонаучного образования: дис. ... канд. пед. наук. Волгоград, 2002. 215 с.

[11] Корнилов В.С. О междисциплинарном характере исследований причинно-следственных обратных задач // Вестник Московского городского педагогического университета. Серия: Информатика и информатизация образования. 2004. № 1 (2). С. 80-83.

[12] Корнилов B.C. Некоторые обратные задачи идентификации параметров математических моделей: учебное пособие. М.: МГПУ, 2005. 359 с.

[13] Корнилов B.C. Гуманитарная компонента прикладного математического образования // Вестник Московского городского педагогического университета. Серия: Информатика и информатизация образования. 2006. № 2 (7). С. 94-99.

[14] Корнилов В.C. Обучение обратным задачам для дифференциальных уравнений как фактор гуманитаризации математического образования: монография. М.: МГПУ, 2006. 320 с.

[15] Корнилов B.C. Гуманитарные аспекты вузовской системы прикладной математической подготовки // Наука и школа. 2007. № 5. С. 23-28. 
[16] Корнилов В.C. Гуманитарный анализ математических моделей обратных задач // Известия Курского государственного технического университета. 2008. № 3 (24). С. 60-65.

[17] Корнилов В.С. Психологические аспекты обучения студентов вузов фрактальным множествам // Вестник Российского университета дружбы народов. Серия: Информатизация образования. 2011. № 4. С. 79-82.

[18] Корнилов B.C. Лабораторные занятия как форма организации обучения студентов фрактальным множествам // Вестник Московского городского педагогического университета. Серия: Информатика и информатизация образования. 2012. № 1 (23). С. 60-63.

[19] Корнилов B.C. Обратные задачи в содержании обучения прикладной математике // Вестник Российского университета дружбы народов. Серия: Информатизация образования. 2014. № 2. С. 109-118.

[20] Корнилов В.С. Обучение студентов обратным задачам математической физики как фактор формирования фундаментальных знаний по интегральным уравнениям // Бюллетень лаборатории математического, естественнонаучного образования и информатизации. Рецензируемый сборник научных трудов. Самара: Самарский филиал МГПУ, 2015. Т. VI. C. $251-257$.

[21] Корнилов В.С. Обучение студентов обратным задачам для дифференциальных уравнений как фактор формирования компетентности в области прикладной математики // Вестник Российского университета дружбы народов. Серия: Информатизация образования. 2015. № 1. C. 63-72.

[22] Корнилов B.C. Реализация научно-образовательного потенциала обучения студентов вузов обратным задачам для дифференциальных уравнений // Казанский педагогический журнал. 2016. № 6. С. 55-59.

[23] Корнилов B.C. Базовые понятия информатики в содержании обучения обратным задачам для дифференциальных уравнений // Вестник Российского университета дружбы народов. Серия: Информатизация образования. 2016. № 1. С. 70-84.

[24] Корнилов B.C. Теория и методика обучения обратным задачам для дифференциальных уравнений: монография. М.: ОнтоПринт, 2017. 500 с.

[25] Корнилов B.C. Формирование фундаментальных знаний по математическому моделированию при обучении обратным задачам для дифференциальных уравнений // Вестник Московского городского педагогического университета. Серия: Информатика и информатизация образования. 2017. № 1 (39). С. 92-99.

[26] Корнилов B.C. Философская составляющая научно-образовательного потенциала обучения обратным задачам математической физики // Вестник Московского городского педагогического университета. Серия: Информатика и информатизация образования. 2018. № 1 (43). C. 59-65.

[27] Корнилов B.C. Формирование у студентов междисциплинарных научных знаний при обучении обратным задачам для дифференциальных уравнений // Вестник Казахского национального педагогического университета имени Абая. Серия: Физико-математические науки. 2018. № 4 (64). С. 46-50.

[28] Кравеи A.C. Гуманизация и гуманитаризация высшего образования // Вестник Воронежского государственного университета. Серия: Проблемы высшего образования. 2000. № 1. C. $30-37$.

[29] Лаврентьев Г.В. Гуманитаризация высшего математического образования на основе блочно-модульного подхода: дис. ... Д-ра пед. наук. Барнаул, 2001. 349 с.

[30] Левченко И.В., Корнилов В.С., Беликов В.В. Роль информатики в подготовке специалистов по прикладной математике // Вестник Московского городского педагогического университета. Серия: Информатика и информатизация образования. 2009. № 2 (18). C. $108-112$.

[31] Павловский Ю.Н. Имитационное моделирование сложных процессов и систем // Современные проблемы прикладной математики: сб. науч. статей. Вып. 1. М.: МЗ Пресс, 2005. C. 75-98. 
[32] Романов В.Г. Обратные задачи для дифференциальных уравнений: спецкурс для студентов НГУ. Новосибирск: НГУ, 1973. 252 с.

[33] Романов В.Г. Обратные задачи математической физики: монография. М.: Наука, 1984. $264 \mathrm{c}$.

[34] Самарский А.А., Вабишевич П.Н. Численные методы решения обратных задач математической физики: монография. М.: УРСС, 2004. 478 с.

[35] Симонов В.M. Дидактические основы естественнонаучного образования: теория и практика реализации гуманитарной парадигмы: дис. ... Д-ра пед. наук. Волгоград, 2000. 403 с.

[36] Тимофеев Ю.М., Поляков А.В. Математические аспекты решения обратных задач атмосферной оптики: учебное пособие. СПб.: Изд-во Санкт-Петербургского университета, 2001. $188 \mathrm{c}$.

[37] Файрушина С.М. Формирование экологической культуры студентов педагогических вузов в процессе изучения естественнонаучных дисциплин: дис. ... канд. пед. наук. Казань, 2007. $217 \mathrm{c}$.

[38] Юрко В.А. Введение в теорию обратных спектральных задач: учебное пособие. М.: Физматлит, 2007. $384 \mathrm{c}$.

\section{История статьи:}

Дата поступления в редакцию: 25 июня 2018

Дата принятия к печати: 30 июля 2018

\section{Для цитирования:}

Kornilov V.S. Humanitarian knowledge in the learning content to the inverse problems for differential equations (Гуманитарные знания в содержании обучения обратным задачам для дифференциальных уравнений) // Вестник Российского университета дружбы народов. Серия: Информатизация образования. 2018. T. 15. № 4. C. 398-409. DOI 10.22363/23128631-2018-15-4-398-409

\section{Сведения об авторе:}

Корнилов Виктор Семенович, доктор педагогических наук, кандидат физико-математических наук, профессор, заместитель заведующего кафедрой информатизации образования Московского городского педагогического университета. Контактная информация: e-mail: vs_kornilov@mail.ru 